\title{
Microbacterium mitrae sp. nov., isolated from salted turban shell
}

\author{
Yun-Ji Kim, Seong Woon Roh, Mi-Ja Jung, Min-Soo Kim, Eun-Jin Park \\ and Jin-Woo Bae
}

Correspondence Jin-Woo Bae baejw@khu.ac.kr

\author{
Department of Life and Nanopharmaceutical Sciences and Department of Biology, Kyung Hee \\ University, Seoul 130-701, Republic of Korea
}

The genus Microbacterium was first described by OrlaJensen (1919) and members of the genus can be isolated from a wide range of environments including soil, insects, human clinical specimens, marine environments and plants (Evtushenko \& Takeuchi, 2006; Park et al., 2008; Bakir et al., 2008; Takeuchi \& Hatano, 1998a, b; Lee et al., 2006; Shivaji et al., 2007; Collins \& Bradbury, 1992). Members of the genus have also been found in the phyllospheres of sugar beet and spring wheat and as endophytes in sweetcorn and cotton (Thompson et al., 1993; Legard et al., 1994; McInroy \& Kloepper, 1995).

In this study, a novel isolate (strain M4- $8^{\mathrm{T}}$ ) belonging to the genus Microbacterium was isolated from salted turban shell, which is a traditional fermented food from Korea. The cultured cell biomass for cellular composition analysis and DNA extraction was collected from marine agar (MA; BBL) plates incubated at $30{ }^{\circ} \mathrm{C}$ for 2 days. The Gram reaction was performed using the non-staining method described by Buck (1982). Motility was examined by the wet-mount method and spore formation was analysed using the staining method of Schaeffer \& Fulton (1933). Cell morphology was observed under a Nikon phasecontrast microscope at $\times 1000$ magnification using cells grown for 2 days at $30{ }^{\circ} \mathrm{C}$ on MA plates. Growth at

The GenBank/EMBL/DDBJ accession number for the 16S rRNA gene sequence of strain M4-8 ${ }^{\top}$ is GQ351351. different temperatures $\left(4,15,25,30,37\right.$ and $\left.45{ }^{\circ} \mathrm{C}\right)$ and $\mathrm{pH}$ (3.0-13.0 at intervals of $1.0 \mathrm{pH}$ unit) was assessed on marine broth (MB; $\mathrm{BBL})$. $\mathrm{NaCl}$ tolerance was determined at $30{ }^{\circ} \mathrm{C}$ in $\mathrm{MB}$ prepared without $\mathrm{NaCl}$ and then supplemented with $0-10$ (in increments of $1 \%$ ), 15 and $20 \%(\mathrm{w} / \mathrm{v}) \mathrm{NaCl}$. Enzyme activity and utilization of various substrates as sole carbon sources were determined using API 20NE and API ZYM strips according to the manufacturer's instructions (bioMérieux). Casein and starch hydrolysis was tested as described by Smibert \& Krieg (1994). Catalase activity was determined by observing bubble production in $3 \%(\mathrm{v} / \mathrm{v})$ hydrogen peroxide solution and oxidase activity was determined using an oxidase reagent (bioMérieux). Indole and $\mathrm{H}_{2} \mathrm{~S}$ formation were tested as described previously (Benson, 1994).

Strain M4-8 ${ }^{\mathrm{T}}$ was non-spore-forming, Gram-positive, rodshaped and non-motile. After 2 days of incubation on MA at $30{ }^{\circ} \mathrm{C}$, colonies were circular $(0.5-2.0 \mathrm{~mm}$ in diameter $)$, smooth, yellow and convex. Strain M4- $8^{\mathrm{T}}$ was able to grow at $15-37{ }^{\circ} \mathrm{C}$, at $\mathrm{pH} 6.0-9.0$ and in $0-8 \% \mathrm{NaCl}$. Optimal growth conditions were $30{ }^{\circ} \mathrm{C}, \mathrm{pH} 7.0$ and $1 \% \mathrm{NaCl}$. The strain was catalase-positive, oxidase-negative and able to hydrolyse casein but not starch. A detailed species description is presented below. Table 1 lists the characteristics that differentiate strain $\mathrm{M} 4-8^{\mathrm{T}}$ from related members of the genus Microbacterium. 
Table 1. Differential characteristics of strain $M 4-8^{\top}$ and the type strains of closely related species

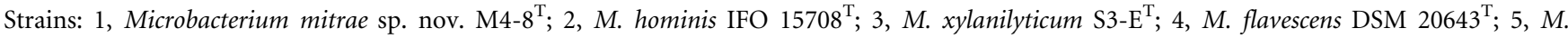
trichothecenolyticum IFO $15077^{\mathrm{T}}$. Data are from this study, except where marked. +, Positive; -, negative.

\begin{tabular}{|c|c|c|c|c|c|}
\hline Characteristic & 1 & 2 & 3 & 4 & 5 \\
\hline Colony morphology & Smooth, yellow & Smooth, yellowish-white & Smooth, yellow & Smooth, yellow & Smooth, yellow \\
\hline $\mathrm{NaCl}$ range (\%) for growth & $0-8$ & $0-3$ & $1-3$ & $0-4$ & $0-4$ \\
\hline Motility & - & - & + & - & - \\
\hline Growth at $37{ }^{\circ} \mathrm{C}$ & + & + & + & - & - \\
\hline Oxidase activity & - & - & + & - & - \\
\hline $\mathrm{H}_{2} \mathrm{~S}$ production & - & + & - & + & + \\
\hline Voges-Proskauer test & - & + & + & - & - \\
\hline Methyl red test & - & + & - & - & - \\
\hline Nitrate reduction & - & - & + & - & + \\
\hline Fermentation of D-glucose & - & - & - & + & - \\
\hline \multicolumn{6}{|l|}{ Hydrolysis of: } \\
\hline Casein & + & - & - & - & - \\
\hline Starch & - & - & - & + & + \\
\hline \multicolumn{6}{|l|}{ Enzyme activity: } \\
\hline Esterase (C4) & + & - & - & - & + \\
\hline Esterase lipase (C8) & + & - & - & - & + \\
\hline Acid phosphatase & + & + & + & - & + \\
\hline DNA G + C content $(\mathrm{mol} \%)$ & 71.3 & $70.9^{\star}$ & $69.7 \dagger$ & $66.9 \ddagger$ & $69.0 \neq$ \\
\hline Major cell-wall diamino acid\$ & Orn & Lys $^{*}$ & Orn $\dagger$ & Orn $\ddagger$ & Orn $\neq$ \\
\hline
\end{tabular}

${ }^{\star}$ Data from Takeuchi \& Hatano (1998b).

$\dagger$ Data from Kim et al. (2005).

$\ddagger$ Data from Yokota et al. (1993).

§orn, Ornithine; Lys, lysine.

Fatty acid methyl esters were obtained from cells grown in $\mathrm{MB}$ medium for 2 days at $30{ }^{\circ} \mathrm{C}$ and analysed by GC-MS (Kuykendall et al., 1988). For quantitative analysis of cellular fatty acid composition, a loop of cell mass was harvested after 2 days and cellular fatty acids were saponified, methylated and extracted according to the Sherlock Microbial Identification System (MIDI) as described by Sasser (1990). The amino acid composition of the cell-wall peptidoglycan was determined after hydrolysis with $6 \mathrm{M} \mathrm{HCl}$ at $100{ }^{\circ} \mathrm{C}$ for $16 \mathrm{~h}$ as described by Schleifer (1985). The predominant cellular fatty acids found in strain M4- $8^{\mathrm{T}}$ were iso- $\mathrm{C}_{15: 0}(55.0 \%)$ and anteiso$\mathrm{C}_{15: 0}(26.5 \%)$. Minor fatty acids were iso- $\mathrm{C}_{16: 0}(7.5 \%)$, iso- $\mathrm{C}_{17: 0}(6.1 \%)$, anteiso- $\mathrm{C}_{17: 0}(2.4 \%)$, iso- $\mathrm{C}_{14: 0}(2.3 \%)$ and $\mathrm{C}_{16: 0}(0.3 \%)$. No hydroxyl fatty acids were identified. The cellular fatty acid profile was consistent with those of other members of the genus Microbacterium. The cell-wall diamino acids were ornithine (major) and lysine.

Chromosomal DNA was extracted using a DNA extraction kit (iNtRON Biotechnology). The 16S rRNA gene sequence was PCR-amplified from chromosomal DNA using PCR Pre-Mix (Solgent) and two bacterial universal primers (Baker et al., 2003). The PCR product was purified using a PCR purification kit (Qiagen) and sequencing was performed as previously described (Roh et al., 2008). Almost full-length $16 \mathrm{~S}$ rRNA gene sequences were assembled using SeqMan software (DNASTAR). The 16S rRNA gene sequence of the novel isolate was aligned with those of related taxa obtained from the NCBI database using the multiple sequence alignment program CLUSTAL $\mathrm{X}$ (1.8) (Thompson et al., 1997). The phylogenetic relationship between representatives of the genus Microbacterium was determined using the MEGA3 software program (Kumar et al., 2004). Distance matrices were determined using the method of Kimura (1980) and used to produce a dendrogram using the neighbour-joining (Saitou \& Nei, 1987), minimum evolution (Rzhetsky \& Nei, 1992) and maximum-parsimony (Kluge \& Farris, 1969) methods. Bootstrap analysis evaluating the stability of the resulting trees was performed using a consensus tree based on 1000 randomly generated trees. DNA-DNA hybridization experiments were performed in triplicate using the fluorometric method of Ezaki et al. (1989). Hybridizations were determined at $37{ }^{\circ} \mathrm{C}$, fluorescence values were quantified at $90 \mathrm{~min}$ using Synergy Mx (BioTek) and hybridization values were calculated as described previously (Chang et al., 2008). Phylogenetic analysis based on $16 \mathrm{~S}$ rRNA gene sequences indicated that strain $\mathrm{M} 4-8^{\mathrm{T}}$ is related to members of the genus Microbacterium. Comparison of the $16 \mathrm{~S}$ rRNA gene sequence of strain M4- $8^{T}$ against those of known species of the genus Microbacterium using FASTA (EMBL/GenBank) showed that it had highest similarity with that of Microbacterium 
hominis IFO $15708^{\mathrm{T}}$ (97.8\%), followed by Microbacterium

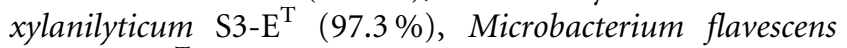
DSM $20643^{\mathrm{T}}(97.1 \%)$ and Microbacterium trichothecenolyticum IFO $15077^{\mathrm{T}}(97.1 \%)$. The clustering and phylogenetic tree drawn using the neighbour-joining, minimumevolution and maximum-parsimony method is shown in
Fig. 1. Phylogenetic trees based on $16 \mathrm{~S}$ rRNA gene sequences showed a similar topology, regardless of the tree-making algorithm used (Fig. 1). DNA-DNA hybridization experiments were performed to determine the genomic relationship between the isolate and those strains with the greatest $16 \mathrm{~S}$ rRNA gene sequence similarity $(\geqslant 97.0 \%)$. DNA-DNA

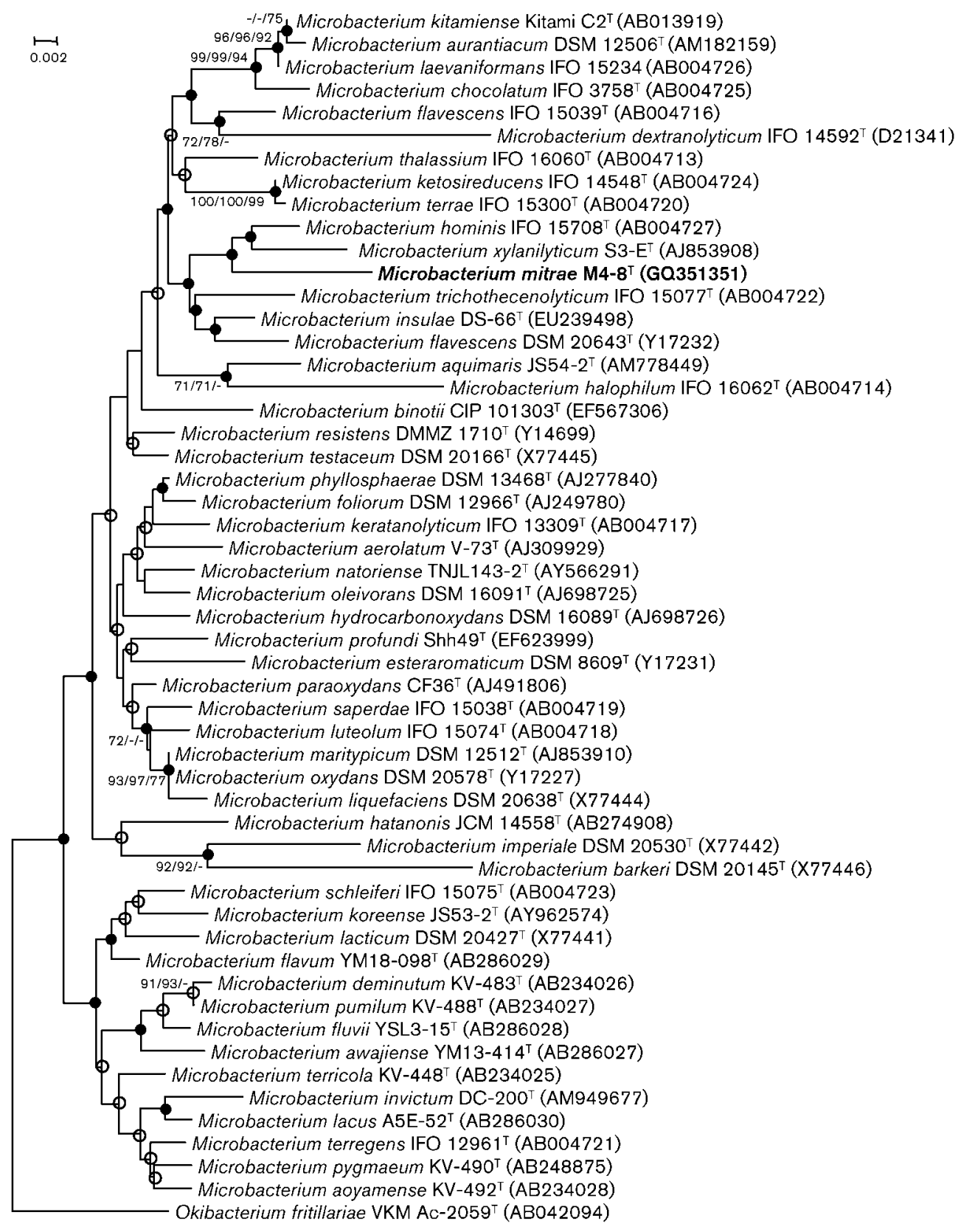

Fig. 1. Phylogenetic tree based on $16 \mathrm{~S}$ rRNA gene sequences. The position of strain $M 4-8^{\top}$ is shown with respect to other species of the genus Microbacterium. Phylogenetic trees were generated using the neighbour-joining and maximum-parsimony methods. GenBank accession numbers are shown in parentheses. Filled circles indicate generic branches that were also recovered using the neighbour-joining (NJ), minimum-evolution (ME) and maximum-parsimony (MP) algorithms. Open circles indicate that the corresponding node was also recovered in the trees generated by two algorithms (NJ and ME, ME and MP, or $\mathrm{NJ}$ and MP). Numbers at nodes indicate bootstrap values $(>70 \%)$ as calculated on the basis of NJ/ME/MP probabilities expressed as percentages of 1000 replications. Bar, 0.002 accumulated changes per nucleotide. 
relatedness ranged from $3.2-28.8 \%$ with its closest relatives: M. hominis IFO $15708^{\mathrm{T}}(17.0 \%)$, M. xylanilyticum S3- $\mathrm{E}^{\mathrm{T}}$ (15.9\%), M. flavescens DSM $20643^{\mathrm{T}}(3.2 \%)$ and $M$. trichothecenolyticum IFO $15077^{\mathrm{T}}(28.8 \%)$. The level of $16 \mathrm{~S}$ rRNA gene sequence similarity coupled with low DNADNA relatedness values below the $70 \%$ threshold (Wayne et al., 1987) indicate that strain $M 4-8^{\mathrm{T}}$ represents a distinct genospecies.

Data for growth of strain $\mathrm{M} 4-8^{\mathrm{T}}$ and its closely related phylogenetic neighbours at various $\mathrm{NaCl}$ concentrations show that strain $\mathrm{M} 4-8^{\mathrm{T}}$ has more $\mathrm{NaCl}$ tolerance than the four most closely related species. Casein hydrolysis can also be used to differentiate between strain $\mathrm{M} 4-8^{\mathrm{T}}$ and its closest relatives (Table 1). Data from $16 \mathrm{~S}$ rRNA gene sequence analysis, DNA-DNA relatedness experiments, and physiological and biochemical tests highlighted genotypic and phenotypic differences between strain M4$8^{\mathrm{T}}$ and other species of the genus Microbacterium. Therefore, it is concluded that strain M4- $8^{\mathrm{T}}$ (=KACC $21129^{\mathrm{T}}=\mathrm{JCM} 16363^{\mathrm{T}}$ ) represents a novel species of the genus Microbacterium, for which the name Microbacterium mitrae sp. nov. is proposed.

\section{Description of Microbacterium mitrae sp. nov.}

Microbacterium mitrae [mi'trae. L. n. mitra a headband, coif, turban of the Asiatics, also a zoological genus name (Mitra); L. gen. n. mitrae of Mitra sp.].

Cells are Gram-positive, non-motile, non-spore-forming and rod-shaped, forming yellow-pigmented, round colonies with a diameter of $0.5-2.0 \mathrm{~mm}$ after incubation for 2 days on $\mathrm{MB}$ agar plates at $30^{\circ} \mathrm{C}$. Growth occurs with 0 $8 \% \mathrm{NaCl}$, at $15-37{ }^{\circ} \mathrm{C}$ and at $\mathrm{pH} 6.0-9.0$, with optimal growth occurring in $1 \%(\mathrm{w} / \mathrm{v}) \mathrm{NaCl}$, at $30{ }^{\circ} \mathrm{C}$ and at $\mathrm{pH}$ 7.0. Does not reduce nitrate to nitrite and does not produce indole. Catalase-positive and oxidase-negative. Casein is hydrolysed, but starch is not. $\mathrm{H}_{2} \mathrm{~S}$ is not formed. Results from the API 20NE system show that the strain hydrolyses aesculin ferric citrate, gelatin and 4-nitrophenyl- $\beta$-D-galactopyranoside, but not D-glucose, L-arginine, urea, L-arabinose, D-mannose, D-mannitol, $\mathrm{N}$-acetylglucosamine, maltose, potassium gluconate, capric acid, adipic acid, malic acid, trisodium citrate or phenylacetic acid. Assays using the API ZYM system are positive for esterase (C4), esterase lipase (C8), leucine arylamidase, acid phosphatase, naphthol-AS-BI-phosphohydrolase and $\alpha$ glucosidase, but negative for lipase (C14), valine arylamidase, cystine arylamidase, trypsin, $\alpha$-chymotrypsin, $\alpha$ galactosidase, $\beta$-glucuronidase, $\beta$-glucosidase, $\beta$-galactosidase, $N$-acetyl- $\beta$-glucosaminidase, $\alpha$-mannosidase and $\alpha$ fucosidase. The predominant fatty acids are iso- $\mathrm{C}_{15: 0}$ and anteiso- $\mathrm{C}_{15: 0}$. Minor fatty acids are iso- $\mathrm{C}_{16: 0}$, iso- $\mathrm{C}_{17: 0}$, anteiso- $\mathrm{C}_{17: 0}$, iso- $\mathrm{C}_{14: 0}$ and $\mathrm{C}_{16: 0}$. The major cell-wall diamino acid is ornithine.

The type strain is M4-8 $8^{\mathrm{T}}\left(=\mathrm{KACC} 21129^{\mathrm{T}}=\mathrm{JCM} 16363^{\mathrm{T}}\right)$, isolated from salted turban shell, which is a traditional fermented food in Korea. The genomic DNA G + C content of the type strain is $71.3 \mathrm{~mol} \%$.

\section{Acknowledgements}

We thank Dr J. P. Euzéby (Ecole Nationale Vétérinaire, France) for etymological advice. This work was supported by the TDPAF (Technology Development Program for Agriculture and Forestry).

\section{References}

Baker, G. C., Smith, J. J. \& Cowan, D. A. (2003). Review and reanalysis of domain-specific $16 \mathrm{~S}$ primers. J Microbiol Methods 55, 541555.

Bakir, M. A., Kudo, T. \& Benno, Y. (2008). Microbacterium hatanonis sp. nov., isolated as a contaminant of hairspray. Int $J$ Syst Evol Microbiol 58, 654-658.

Benson, H. J. (1994). Microbiological Applications: a Laboratory Manual in General Microbiology, 6th edn. Dubuque, IA: Wm. C. Brown.

Buck, J. D. (1982). Nonstaining $(\mathrm{KOH})$ method for determination of Gram reactions of marine bacteria. Appl Environ Microbiol 44, 992993.

Chang, H.-W., Nam, Y.-D., Jung, M. Y., Kim, K.-H., Roh, S. W., Kim, M.-S., Jeon, C. O., Yoon, J.-H. \& Bae, J.-W. (2008). Statistical superiority of genome-probing microarrays as genomic DNA-DNA hybridization in revealing the bacterial phylogenetic relationship compared to conventional methods. J Microbiol Methods 75, 523-530.

Collins, M. D. \& Bradbury, J. F. (1992). The genera Agromyces, Aureobacterium, Clavibacter, Curtobacterium and Microbacterium. In The Prokaryotes, 2nd edn, pp. 1355-1368. Edited by A. Balows, H. G. Trüper, M. Dworkin, W. Harder \& K. H. Schleifer. New York: Springer.

Evtushenko, L. I. \& Takeuchi, M. (2006). The family Microbacteriaceae. In The Prokaryotes: a Handbook on the Biology of Bacteria, 3rd edn, vol. 3, pp. 1020-1098. Edited by M. Dworkin, S. Falkow, E. Rosenberg, K. H. Schleifer \& E. Stackebrandt. New York: Springer.

Ezaki, T., Hashimoto, Y. \& Yabuuchi, E. (1989). Fluorometric deoxyribonucleic acid-deoxyribonucleic acid hybridization in microdilution wells as an alternative to membrane filter hybridization in which radioisotopes are used to determine genetic relatedness among bacterial strains. Int J Syst Bacteriol 39, 224-229.

Kim, K. K., Park, H. Y., Park, W., Kim, I. S. \& Lee, S.-T. (2005). Microbacterium xylanilyticum sp. nov., a xylan-degrading bacterium isolated from a biofilm. Int J Syst Evol Microbiol 55, 2075-2079.

Kimura, M. (1980). A simple method for estimating evolutionary rates of base substitutions through comparative studies of nucleotide sequences. J Mol Evol 16, 111-120.

Kluge, A. G. \& Farris, F. S. (1969). Quantitative phyletics and the evolution of anurans. Syst Zool 18, 1-32.

Kumar, S., Tamura, K. \& Nei, M. (2004). MEGA3: integrated software for molecular evolutionary genetics analysis and sequence alignment. Brief Bioinform 5, 150-163.

Kuykendall, L. D., Roy, M. A., O'Neill, J. J. \& Devine, T. E. (1988). Fatty acids, antibiotic resistance, and deoxyribonucleic acid homology groups of Bradyrhizobium japonicum. Int J Syst Bacteriol 38, 358-361.

Lee, J.-S., Lee, K. C. \& Park, Y.-H. (2006). Microbacterium koreense sp. nov., from sea water in the South Sea of Korea. Int J Syst Evol Microbiol 56, 423-427. 
Legard, D. E., McQuilken, M. P., Whipps, J. M., Fenlon, J. S., Fermor, T. R., Thompson, I. P., Bailey, M. J. \& Lynch, J. M. (1994). Studies of seasonal changes in the microbial populations on the phyllosphere of spring wheat as a prelude to the release of a genetically modified microorganism. Agric Ecosyst Environ 50, 87-101.

McInroy, J. A. \& Kloepper, J. W. (1995). Survey of indigenous bacterial endophytes from cotton and sweet corn. Plant Soil 173, 337-342.

Orla-Jensen, S. (1919). The Lactic Acid Bacteria. Copenhagen: Høst and Son.

Park, M.-J., Kim, M. K., Kim, H.-B., Im, W.-T., Yi, T.-H., Kim, S.-Y., Soung, N.-K. \& Yang, D.-C. (2008). Microbacterium ginsengisoli sp. nov., a $\beta$-glucosidase producing bacterium isolated from soil of a ginseng field. Int J Syst Evol Microbiol 58, 429-433.

Roh, S. W., Sung, Y., Nam, Y.-D., Chang, H.-W., Kim, K.-H., Yoon, J.-H., Jeon, C. O., Oh, H.-M. \& Bae, J.-W. (2008). Arthrobacter soli sp. nov., a novel bacterium isolated from wastewater reservoir sediment. J Microbiol 46, 40-44.

Rzhetsky, A. \& Nei, M. (1992). A simple method for estimating and testing minimum-evolution trees. Mol Biol Evol 9, 945-967.

Saitou, N. \& Nei, M. (1987). The neighbor-joining method: a new method for reconstructing phylogenetic trees. Mol Biol Evol 4, 406-425.

Sasser, M. (1990). Identification of bacteria by gas chromatography of cellular fatty acids, MIDI Technical Note 101. Newark, DE: MIDI Inc.

Schaeffer, A. B. \& Fulton, M. D. (1933). A simplified method of staining endospores. Science 77, 194.

Schleifer, K. H. (1985). Analysis of the chemical composition and primary structure of murein. Methods Microbiol 18, 123-156.

Shivaji, S., Bhadra, B., Rao, R. S., Chaturvedi, P., Pindi, P. K. \& Raghukumar, C. (2007). Microbacterium indicum sp. nov., isolated from a deep-sea sediment sample from the Chagos Trench, Indian Ocean. Int J Syst Evol Microbiol 57, 1819-1822.
Smibert, R. M. \& Krieg, N. R. (1994). Phenotypic characterization. In Methods for General and Molecular Bacteriology, pp. 607-654. Edited by P. Gerhardt, R. G. E. Murray, W. A. Wood \& N. R. Krieg. Washington, DC: American Society for Microbiology.

Takeuchi, M. \& Hatano, K. (1998a). Union of the genera Microbacterium Orla-Jensen and Aureobacterium Collins et al. in a redefined genus Microbacterium. Int J Syst Bacteriol 48, 739747.

Takeuchi, M. \& Hatano, K. (1998b). Proposal of six new species in the genus Microbacterium and transfer of Flavobacterium marinotypicum ZoBell and Upham to the genus Microbacterium as Microbacterium maritypicum comb. nov. Int J Syst Bacteriol 48, 973-982.

Thompson, I. P., Bailey, M. J., Fenlon, J. S., Fermor, T. R., Lilley, A. K., Lynch, J. M., McCormack, P. J., McQuilken, M. P., Purdy, K. J. \& other authors (1993). Quantitative and qualitative seasonal changes in the microbial community from the phyllosphere of sugar beet (Beta vulgaris). Plant Soil 150, 177-191.

Thompson, J. D., Gibson, T. J., Plewniak, F., Jeanmougin, F. \& Higgins, D. G. (1997). The CLUSTAL_X windows interface: flexible strategies for multiple sequence alignment aided by quality analysis tools. Nucleic Acids Res 25, 4876-4882.

Wayne, L. G., Brenner, D. J., Colwell, R. R., Grimont, P. A. D., Kandler, O., Krichevsky, M. I., Moore, L. H., Moore, W. E. C., Murray, R. G. E. \& other authors (1987). International Committee on Systematic Bacteriology. Report of the ad hoc committee on reconciliation of approaches to bacterial systematics. Int $J$ Syst Bacteriol 37, 463-464.

Yokota, A., Takeuchi, M., Sakane, T. \& Weiss, N. (1993). Proposal of six new species in the genus Aureobacterium and transfer of Flavobacterium esteraromaticum Omelianski to the genus Aureobacterium as Aureobacterium esteraromaticum comb. nov. Int J Syst Bacteriol 43, $555-564$. 